\title{
The Donation Act of Hagi Constantin Pop's Family for the Annunciation Church in Sibiu
}

\author{
Constantin Oancea * (D) and Ioan Ovidiu Abrudan
}

Faculty of Theology, Lucian Blaga University of Sibiu, 550179 Sibiu, Romania; abrudanioanovidiu@yahoo.com

* Correspondence: constantin.oancea@ulbsibiu.ro

Received: 21 January 2020; Accepted: 24 February 2020; Published: 27 February 2020

check for updates

\begin{abstract}
This article presents an important document relating to the history of an Orthodox church in Sibiu (Biserica din Groapă), whose construction was possible due to the support provided by the family of the wealthy Macedonian-Romanian merchant Hagi Constantin Pop, at the beginning of the nineteenth century. After a thorough description of the document, we will provide both the German transcription and the English translation of the text. The notes and comments that accompany the document are meant to shed light upon the historical context in which the church was raised and to emphasize the importance of the document, which is the oldest one preserved in the archives of the Annunciation Church. The document mentions the gift of charity by the widow of Hagi Constantin Pop, whereby the land on which the church, its surrounding cemetery, the parish house, and the Romanian school were built would become the property of the Orthodox Church. Thus, the document presents the circumstances under which the patrimony of the foundation patronized by the members of Hagi Constantin Pop's family was constituted. That foundation continued to administer the patrimony of the Annunciation Church until the establishment of the Communist regime in Romania.
\end{abstract}

Keywords: orthodox church in the Austro-Hungarian empire; Biserica din Groapă; patronized church; Hagi Constantin Pop; Andrei șaguna; kurrentschrift; C\&I Honig

\section{Introduction}

Sibiu (German: Hermannstadt) was founded in the twelfth century by colonists originating from Alsace-Lorraine, Luxembourg, Flanders, and Germany. In historical sources, they are referred to as Saxones. Their mission was to provide military protection to the southeastern area of Transylvania against possible attacks from beyond the Carpathians. The location of Sibiu at the intersection of two main trade routes led to the economic development of the entire region inhabited by the Saxons, called Royal Lands (Fundus Regius) and comprising administrative subunits called chairs. By the end of the fourteenth century, the Saxon patricians managed to turn Hermannstadt into a prosperous city, a commercial metropolis. Sibiu became the capital of the Saxon nation of Transylvania (Roth 2006, pp. 3-57). In 1543, Sibiu became evangelical, with Transylvania being one of the first regions in Europe where the Reformation was adopted (Wien 2017, pp. 9-16).

The territory of medieval Transylvania was divided among socio-ethnic estates called nations: the Hungarian nobility, the Saxons, and the Szeklers. The estate of the Romanians, called Universitas Valachorum, was not able to maintain itself and ceased to exist in the fourteenth century. Subsequently, the Romanians no longer had political rights and declined to the rank of subjects or even serfs. For reasons of self-protection and preservation of national identity, the Saxon administration sought to 
restrict the right of settlement (concivility) in the cities of the Royal Lands (Teutsch 1907, pp. XXII-XXVI). ${ }^{1}$ During the sixteenth to eighteenth centuries, only Germans were allowed to buy property in the city, and marriages with persons of other ethnicities were forbidden under the penalty of expulsion from the city (Sigerius 1928, pp. 105-6). However, foreigners who occupied important positions and held qualifications that could be performed by no other professional in the city were exempted from that rule (Brusanowski 2007, p. 206). Even Hungarian nobles had to rent an accommodation when attending the meetings of the government in Sibiu. In 1773 and 1776, Empress Maria Theresa confirmed the Saxons' exclusive right to residence (Sigerius 1928, pp. 108-9).

The Romanians lived mainly in the villages around Sibiu. In the eighteenth century, the so-called maieri started to settle into the gardens of the Saxon patricians, located outside the walls of the fortress. ${ }^{2}$ Although the ethnicity of the maieri was not homogeneous, most of these inhabitants of the suburbs were Romanians. A conscription from 1805 stated that 407 families of Orthodox Romanians were living in the suburbs of Sibiu (Brusanowski 2007).

The reforms initiated by Emperor Joseph II (1741-1790) aimed to alleviate the antagonisms existing between the ethnic groups and religious denominationswithin the monarchy. By removing the Germans' exclusive right to residence, the Edict of Concivility of 22 March 1781 had a positive influence upon the lives of the Romanians living in Transylvania. Hungarian nobles, but especially wealthy merchants, were able to purchase and build houses in Sibiu. Among them was Hagi Constantin Pop (Sigerius 1928, p. 114). The majority of Romanians continued to inhabit the suburbs, as in the case of the Iosefin Suburb (German: Joseph Vorstadt), whose building started around the Gate to Cisnădie. Equally beneficial to the Romanians was the Edict of Tolerance of Emperor Joseph II (8 November 1781). The provisions of this edict allowed the Romanians to build churches in Sibiu and in the suburbs of Sibiu.

The Annunciation Orthodox Church is generally called Biserica din Groapă (Church in the Hollow), given its placement on the stream of a little valley. ${ }^{3}$ This first brick Orthodox church in Sibiu was raised outside the city walls, in the Iosefin suburb, at a walking distance of about $1.3 \mathrm{~km}$ from the city center. According to Nicolae Iorga, the new place of worship was built in German style. It was a patronized church, i.e., a gift offered to the community by a single wealthy family. Aspects regarding the history of the church are known from previous research (Iorga 1906c; Bodogae 1981) and from the more recent presentations made by Păcurariu $(2002,2006)$, Soroştineanu $(2010,2014)$, and Abrudan (2013). The document we shall present below ${ }^{4}$ is less known or probably yet undisclosed.

Concluded on 22 May 1814, the notarial document is the oldest document still preserved in the parish archive of the Annunciation Church. It was completed several decades before all the other church documents preserved (writings, letters, and various reports on the wealth, income, and annual expenses for the maintenance of the church and of the school in the Iosefin district), whose registration began to run only in $1850 .{ }^{5}$ However, as evidenced by a handover report of the parish archive, in which documents issued as early as 1799 were mentioned, it seems that equally old or even older documents than the one we shall present actually existed. ${ }^{6}$

V. Sorostineanu used the epigraphic investigation of the funeral monuments in the cemetery of Biserica din Groapă as a historiographical approach (Soroştineanu 2014). The method we apply is that of archival research, used in historical investigations of documents so as to gain access to organizations, individuals, and information of earlier time that otherwise could not be acquired (Ventresca and Mohr 2017). Our interest in the archive of Biserica din Groapă increased during our

1 The Saxons believed that their freedom and autonomy would be threatened if the Hungarian nobility received the right of concivility, because the nobles did not obey the same laws.

The name comes from the German Meier, by which the free peasants who worked the land of an owner were designated.

Other English renderings are Church in the Pit or Church in the Ditch.

BG, Donation Act of Paulina Pop, 22 May 1814, Arhiva parohială, doc. 660/1814.

We managed to identify only one document from 1845, written in Serbian.

BG, Handover report, 27 October 1879, Arhiva parohială, doc. 3022/879. 
work at the monography of this monument of ecclesiastical art. In what follows, we shall start from a detailed description of the document, followed by the German transcript and the English translation of the act. Then, we shall include our comments on the document, which are meant both to frame the act in the context of the history of Biserica din Groapă and to highlight its importance.

\section{The description of the document}

The document is written in black ink on watermarked paper with the following dimensions: $236 \times 356 \mathrm{~mm}$. By folding the paper, two sheets resulted, forming four pages with the dimensions $178 \times 236 \mathrm{~mm}$. The bottom edges of the pages are damaged, probably as a result of the way the document was preserved.

The watermark is placed in the middle of the sheet, but the act was completed with the watermark in inverted position (rotated by 180 degrees). On page 2, the text "C\&I Honig" appears (see Figure 1a); on page 4 , one can see the representation of an emblem with the postal horn on the background of a crowned shield (see Figure 1b).
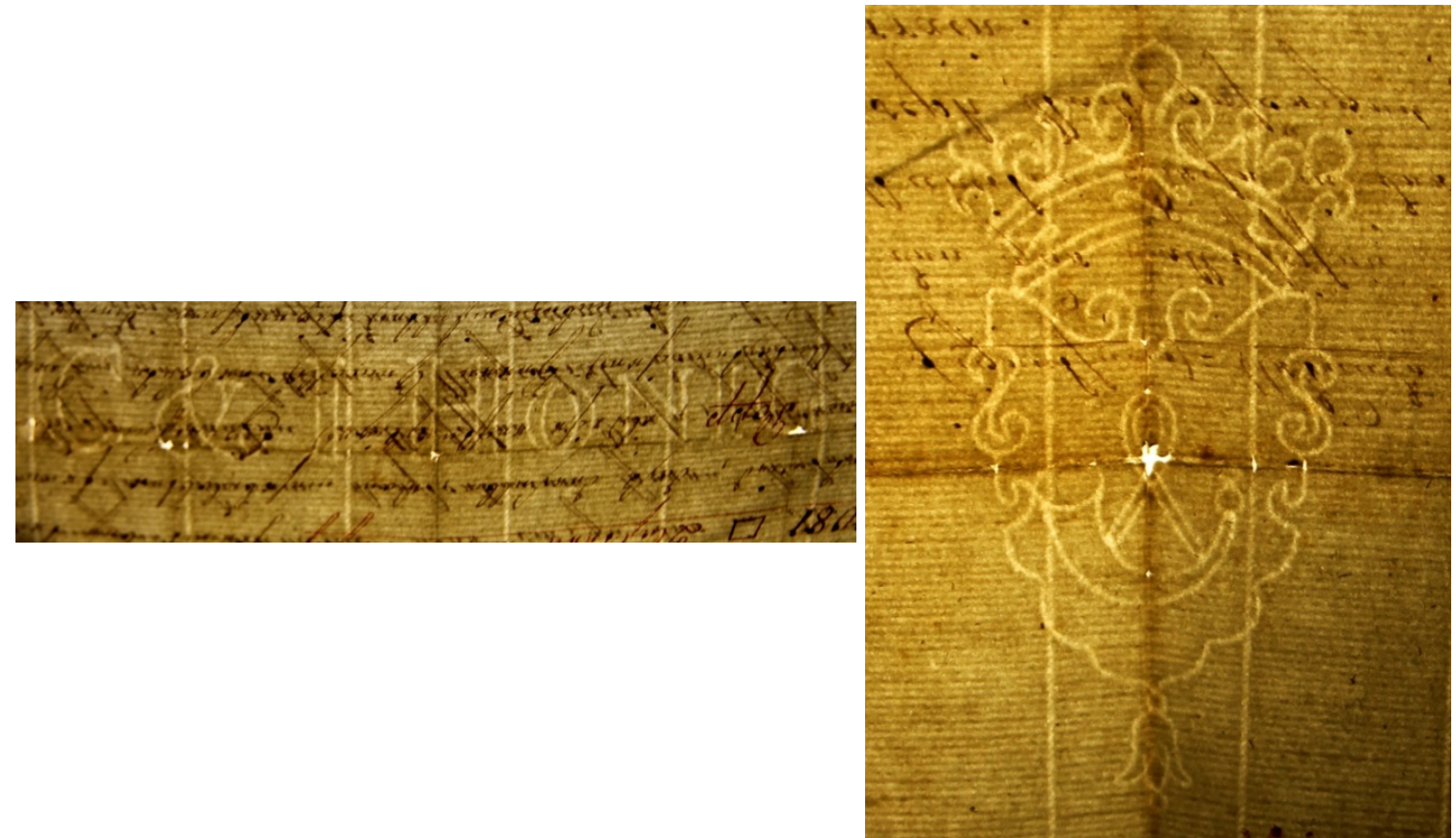

(a)

(b)

Figure 1. (a) Watermark on page 2; (b) watermark on page 4.

The text of the watermark indicates that the paper comes from the paper mill of the brothers Cornelis (1683-1755) and Jan (1688-1757) Honig, from Zaandijk/Holland. The factory, whose beginnings date from 1662 and whose owners changed several times, operated until 1912 (Voorn 1960, p. 554). The paper produced there was of high quality and was widely used in the last decades of the eighteenth and early nineteenth centuries. ${ }^{7}$

7 Many personalities of the time-for example, Georg Wilhelm Friedrich Hegel (Ziesche and Schnitger 1995, p. 72), Clemens Brentano (Härtl 2018, pp. 1962, 1983), or Søren Kierkegaard (Deuser and Purkarthofer 2005, p. 384) - used that type of paper for correspondence or diary entries. Ludwig van Beethoven wrote his late compositions on C\&I Honig paper (Freyhan 2009, p. 74; Goerg 1978, pp. 180-81). Paper with the same watermark as the one appearing on the document to which the present study refers was used for the score of the composition "Wellingtons Sieg, oder die Schlacht bei Vittoria", printed in 1816 (Beethoven 1816; https://www.loc.gov/item/consortium.bh_Bo59_FT00047857/). 
The text of the document is written on pages 1 and 2 (see Figures 2 and 3). The nature of the document (document of ownership) is inscribed at the bottom of page 4 (see Figure 4). The mentioning of "No. 1a" on the last page suggests that several copies of the document were made, and the copy we shall refer to below was the one sent to the owner. On the bottom right, the number 1868/815 can be deciphered, marked by the issuer of the document. At the top of page 4 , the current inventory number of the document in the archive of the Annunciation Church ("660") is mentioned, written over the old inventory number ("Inv 511"). Subsequently, the following entry was added, written in Romanian and in blue ink: "1814/donation act [of] Constantin and Paulina Hagi Popp". Page 3 is empty.

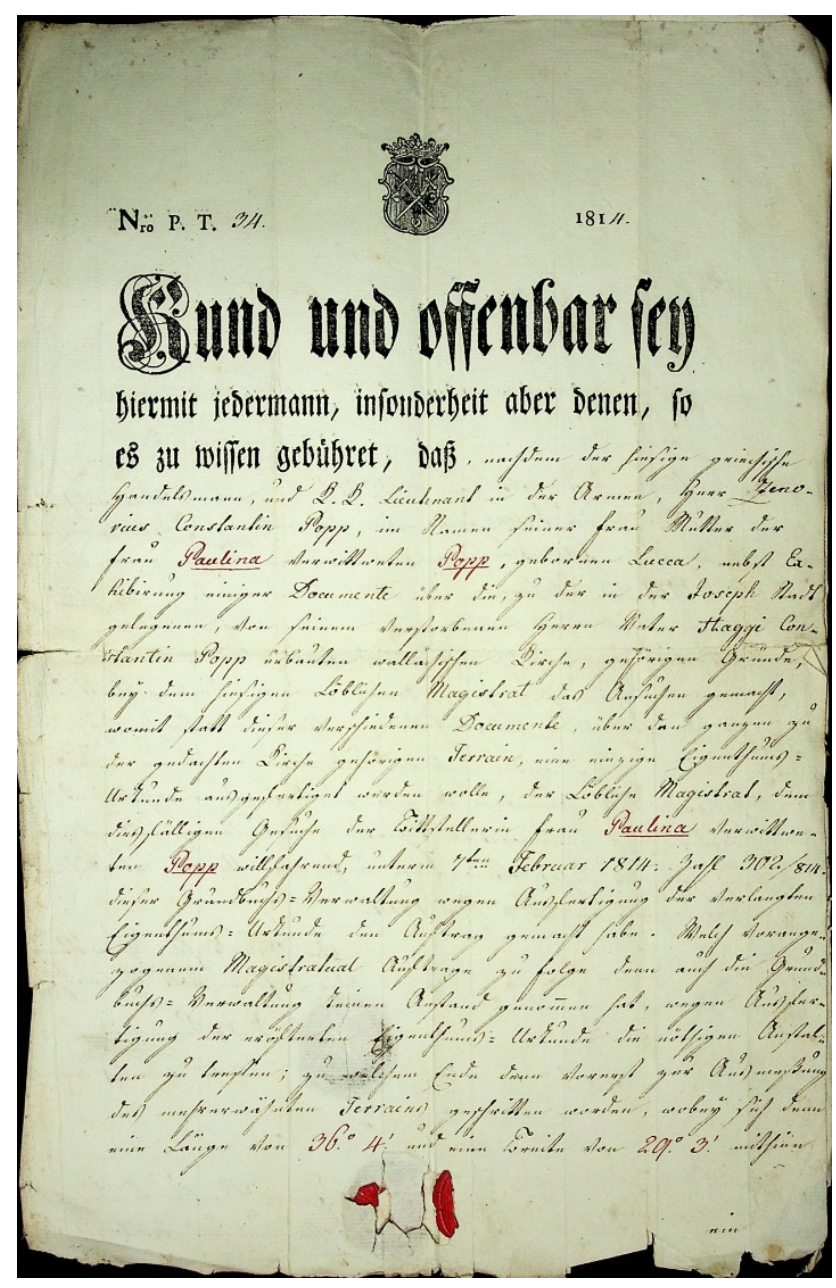

Figure 2. First page of the document. 


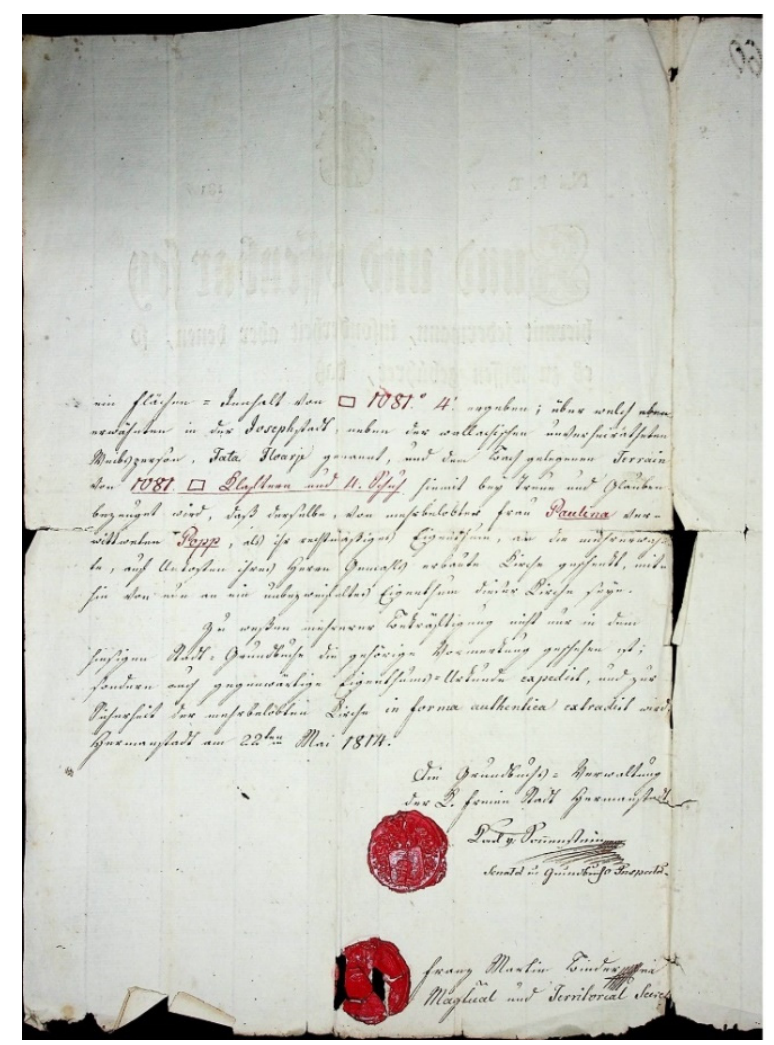

Figure 3. Second page of the document.

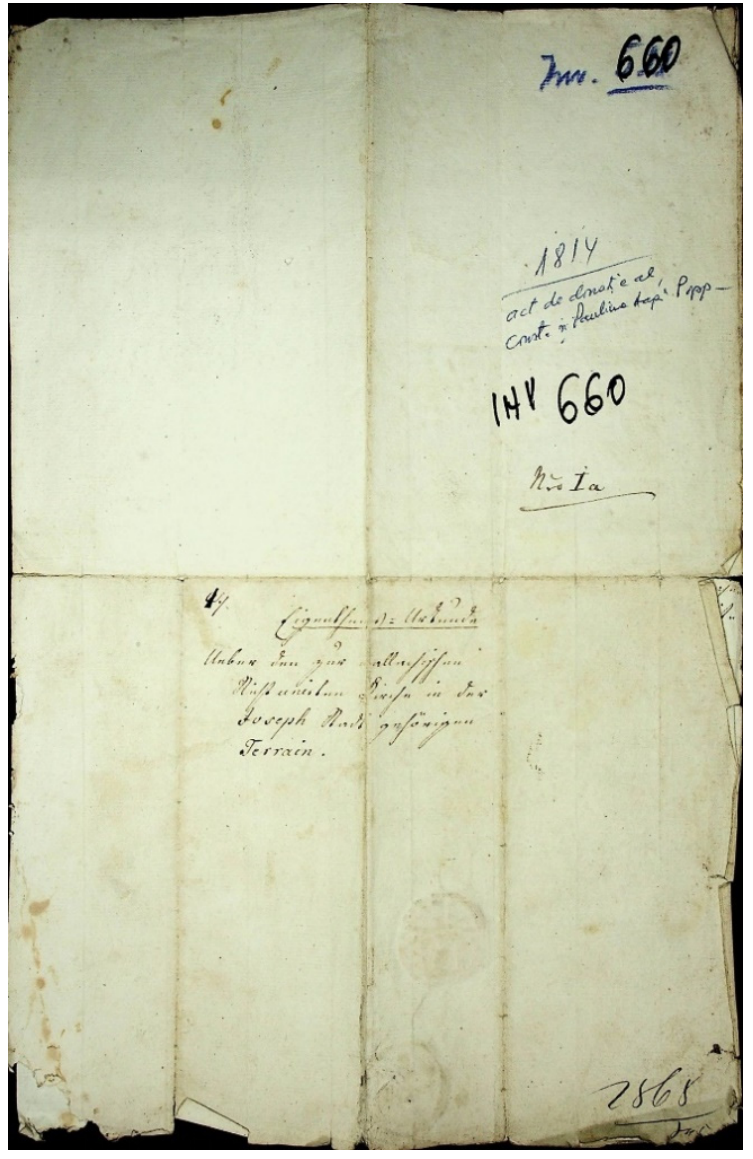

Figure 4. Last page of the document (page 4). 
On page 2, two red wax stamps can be observed, next to which one can see the respective signatures (see Figure 5). The first stamp, on which a heraldic sign with a shield and a helmet with a cluster of feathers can be distinguished, belonged to Carl von Sonnenstein, senator and inspector of the land book, who signed next to it. The stamp corresponds to a description from 1879 of the Sonnenstein family's coat of arms: "on the blue background a rock rises from the green ground, before which a golden sun rises. The crest of the helmet: three ostrich feathers, a golden one in the centre, the other ones being blue. The mantling of the helmet: golden-yellow" (Buschak and Irrgang 1879, p. 587). ${ }^{8}$ The second stamp contains the initials "F B" and belongs to Franz Martin Binder, magistrate and territorial secretary, as evidenced by the accompanying signature. Some data on issuers will be provided in the comment that follows the transcription and the translation of the document.

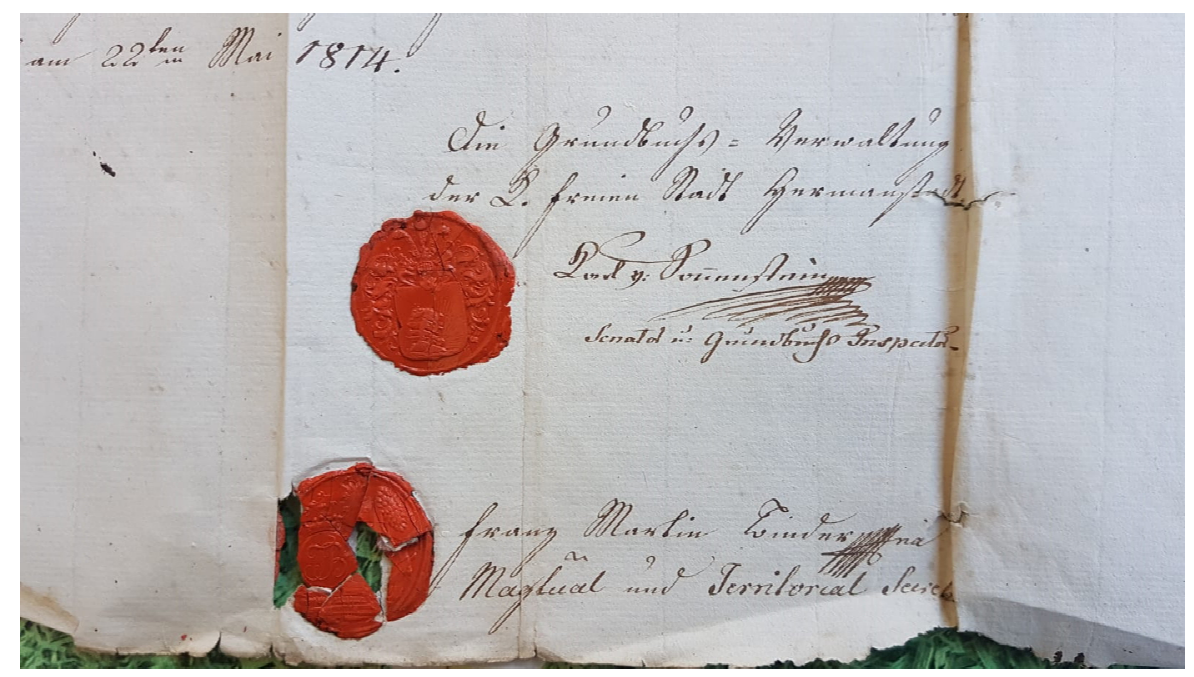

Figure 5. Wax stamps on page 2.

The document is written in German. The form used is typified. The first line of page 1 includes the headings for the document number and the year of issue, which frame the emblem of Sibiu. These sections were completed by the issuer with cursive writing: the number 34 and the year 1814, respectively. The following three rows contain typed text, printed in gothic characters (see Figure 1).

Next, starting with line 3, the document is written with German cursive writing, known as Kurrent (German: Kurrentschrift), used in Austria and Germany until the first half of the twentieth century. ${ }^{9}$ This writing was used in the nineteenth century for correspondence, as well as for the writing of official documents (Jensen 1969, p. 535). In the twentieth century, Kurrent writing gradually fell out of use as a result of a decree of the national socialist government of 1941, which stopped its teaching in schools and required its replacement with Latin writing (Reichsministerium für Wissenschaft, Erziehung und Volksbildung und der Unterrichts-Verwaltung der Länder 1941, pp. 332-33). Straight lines and sharp angles are characteristic of Kurrent writing, a reason why this type of writing is also called sharp (Spitzschrift) or fractured (Fraktur), as opposed to Latin writing (Antiqua), in which the letters are rounded (Jensen 1969, pp. 526-37). One of the graphic features of Kurrent writing at the end of the eighteenth century is the inclination of the letters by approximately 60 degrees, which can also be seen in the document presented here. Starting in the second half of the nineteenth century, with the spread of the metal pen, which required a certain position of the hand, the inclination degree increased to approximately 45 degrees (Steiner-Welz 2003, p. 123). The present document reflects the specificity of

8 All quotations from German and Romanian sources in this article have been translated into English by the authors.

9 Kurrent writing developed from the minuscule Gothic writing of the twelfth and thirteenth centuries and reached a stable form in the sixteenth and the seventeenth centuries, which later witnessed only minor changes brought to the letters (Jensen 1969, pp. 526-37). 
the time by the fact that the names of persons (e.g., "Zenovius Constantin Popp", "Paulina", "Lucca", etc.), Latinisms, or neologisms (e.g., "Lieutenant", "Documente", "Magistrat", etc.) are rendered with normal writing (Antiqua), although most often the letter " $t$ " is written with Kurrent writing in these situations. As in the case of Antiqua humanist writing, two symbols are used for the letter "s"-long, at the beginning of the word or syllable, and round, at the end of the word or syllable (Jensen 1969, p. 534; Seidl 2006, pp. 10-12).

\section{Transcription and Translation of the Document}

When transcribing the document, we also reproduced the page layout so that the same number of rows per page and the same number of words per line are rendered. We also reproduced the spelling of the document, which reflects the state of the German language at the time. The printed text of the template is rendered in bold. Other information or features are written between round brackets, such as page number or position of the wax stamps. In places where the text obviously gave abbreviated forms, we introduce the missing letters between square brackets. The notes that follow the translation contain additional information about abbreviations or units of measurement used in the document.

\subsection{Transcription}

(page 1)

Nro P. T. 34 . (the coat of arms of Sibiu) 1814

Kund und offenbar sey

hiermit jerdermann, insonderheit aber denen, so

es zu wissen gebühret, daß, nachdem der hiesige griechische

Handelsmann, und K.K. ${ }^{a}$ Lieutenant in der Armee, Herr Zeno-

vius Constantin Popp, im Namen seiner Frau Mutter der

Frau Paulina verwittwetten Popp, geborene Lucca, nebst Ex-

hibierung einiger Documente über die, zu der in der Joseph Stadt

gelegenen, von seinem verstorbenen Herrn Vater Haggi Con-

stantin Popp erbauten wallachischen Kirche, gehörigen Gründe,

bey dem hiesigen Löblichen Magistrat das Ansuchen gemacht, womit statt dieser verschiedenen Documente, über den ganzen zu der gedachten Kirche gehörigen Terrain eine einzige EigenthumsUrkunde ausgefertiget werden wolle, der Löbliche Magistrat, dem diesfälligen Gesuche der Bittstellerin Frau Paulina verwittweten Popp willfahrend, unterm 7ten Februar 1814. Zahl 302/814. dieser Grundbuchs-Verwaltung wegen Ausfertigung der verlangten Eigenthums-Urkunde den Auftrag gemacht habe. Welch vorangezogenem Magistratual Auftrage zu Folge dem auch die Grundbuchs-Verwaltung keinen Anstand genom[m]en hat, wegen Ausfertigung der eröfterten Eigenthums-Urkunde die nöthigen Anstalten zu tref[f]en; zu welchem Ende denn vorerst zur Ausmeßung des mehrerwähnten Terrains geschritten worden, wobey sich denn

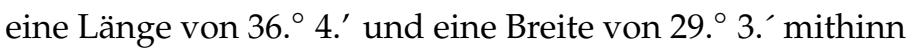

ein

(page 2)

ein Flächen-Innhalt von $\square$ 1081. ${ }^{\circ}$ 4. $^{\prime}$ ergeben ${ }^{b}$; über welch eben erwähnten in der Josephstadt, neben der wallachischen unverheiratheten Weibssperson, Fata ${ }^{c}$ Floarje genannt, und dem Bach gelegenen Terrain von 1081. $\square$ Klaftern und 4. Schuh hiemit ${ }^{\mathrm{d}}$ bey Treue und Glauben 
bezeuget wird, daß derselbe, von mehrbelobter Frau Paulina verwittweten Popp, als ihr rechtmäßiges Eigenthum, an die mehrerwähnte, auf Unkosten ihres Herrn Gemahls erbaute Kirche geschenkt, mithin von nun an ein unbezweifeltes Eigenthum dieser Kirche seye.

$\mathrm{Zu}$ weßen mehrerer Bekräftigung nicht nur in dem

hiesigen Stadt-Grundbuche die gehörige Vormerkung geschehen ist; sondern auch gegenwärtige Eigenthums-Urkunde expedit, und zur Sicherheit der mehrbelobten Kirche in forma authentica extradit wird.

Hermanstadt am 22ten Mai 1814

Die Grundbuchs-Verwaltung

Der K. ${ }^{\text {e }}$ Freien Stadt Hermanstadt

(stamp) Karl v. Sonnestein

Senator und Grundbuchs-Inspector

(stamp) Franz Martin Binder

Mag[istra]tual und Territorial Secre[tär] ${ }^{\mathrm{f}}$

(page 4) ${ }^{g}$

Nro Ia

Eigenthums-Urkunde

Ueber den zur wallachischen

Nichtunierten Kirche in der

Joseph Stadt gehörigen

Terrain

$1868 / 815(?)$

\subsection{Translation}

(page 1)

Nr. 34

(coat of arms of Sibiu)

1814

To anyone who should be notified and acknowledged, especially those who should know this, the fact that, after the local Greek merchant

and lieutenant in the imperial army, Mr. Zenovius Constantin Popp, on behalf of his mother, Mrs. Paulina, widow of Popp, born Lucca, in addition to submitting documents on lands located in Joseph Stadt, belonging to the Wallachian Church, built by his late father Haggi Constantin Popp, submitted the request to the worthy local magistrate, expressing her wish that, instead of these various documents, a single deed of ownership should be issued regarding the entire land belonging to the above-mentioned church, the worthy magistrate ordered to be given effect to this request of the petitioning lady Paulina, widow of Popp, and thus performed the assignment registered with the number 302/814 of February $7 \overline{\text { in the }}$ local land administration, for issuing the requested property document. As a result of the magistrate assignment received, the administration of the land book did not raise objections against taking the necessary measures to issue the mentioned deed of ownership. For this purpose, the above-mentioned land was first measured, resulting a length of $36 .^{\circ} 4 .^{\prime}$ and a width of 29. ${ }^{\circ} 3 .^{\prime}$, therefore

one

(page 2)

an area of $\square 1081 .^{\circ} 4 .^{\prime}$ It is hereby confirmed, honestly and in good faith, that the repeatedly above mentioned land, located in Josephstadt, near (the land) of the unmarried Wallachian female person named Țața Floarie and next to the river, with an area of 
$1081 \square$ fathoms and 4 feet, the rightful property of the much-praised widow Paulina Popp, is donated to the above mentioned church, built at the expense of her husband, and becomes henceforth the undisputed property of this church.

To the multiple express confirmation, the proper record was made not only in the local urban land book, but the present deed of property was also sent, being handed over in authentic form to the much-praised church for guarantee.

Hermannstadt, May 22, 1814

Land book administration

Of the free royal city Hermannstadt

(Stamp) Karl von Sonnestein

Senator and inspector of the land book

(Stamp) Franz Martin Binder

Magistrate and territorial secretary

(page 4)

No. Ia

Property document

Regarding the land located in Josephstadt,

belonging to the Wallachian Orthodox Church

$1868 / 815$ (?)

\subsection{Notes}

a. "K.K." is the abbreviation for kaiserlich-königlich (imperial royal), a title for Austrian officials and institutions before the formation of the dualist monarchy (1867).

b. Signs are symbols for the fathom $\left(^{\circ}\right)$ and foot $\left(^{\prime}\right)$ as units of distance measurement. The square () is a symbol for fathoms and feet as units of surface measurement. The value of a Viennese fathom (klafter) in the first half of the nineteenth century differs slightly in the bibliographic sources: $1.896145 \mathrm{~m}$ (Jäckel 1824, p. 108); $1.896484 \mathrm{~m}$ (Czeike 2004, pp. 520-21). After the year 1871, 1 fathom became $1.896486 \mathrm{~m}$ (Czeike 2004, pp. 520-21). Initially, 1 surface fathom $=3.5979$ $\mathrm{m}^{2}$ (Gernrath 1825, p. 573), and after 1871, it became $3.596652 \mathrm{~m}^{2}$ (Czeike 2004, p. 521). A total of 1 fathom contains 6 Viennese feet, so 1 foot measures approximately $0.316 \mathrm{~m}$ (Krüger 1830, p. 103).

c. The letter " $\mathrm{F}$ " of the word "Fata" is similar to " $\mathrm{T}$ ". Thus, instead of "Fata" (girl, daughter of), it could be "Tata", possibly the German transcription of the word "Tața"-a term of neo-Greek origin used for an older female person (similar to "my old woman", "aunt").

d. Sic! Probably "hiermit".

e. $\quad$ "K" - the short form of Königlichen (royal). Hermannstadt was a royal free city. Very important cities in the Kingdom of Hungary and later in the Austrian Empire used to be designated by this term until 1876.

f. Lit. "Magtual" (probably an abbreviation of the word "magistratual") and "Secre", probably "Secretär", refer to categories of civil servants in the city administration. In the first decades of the nineteenth century, the chair of Sibiu had two "Magistratual-Secretäre" (Ludwig 1828, p. 472).

g. $\quad$ Page 3 is blank.

\section{Discussion}

\subsection{Historical Background}

Before discussing the content of the act, some clarifications regarding the events preceding its issuance are worth noting. By the end of the eighteenth century, large commercial companies founded 
by Macedo-Romanians and Greeks from south of the Danube built up their business throughout the Habsburg monarchy, as did the Greek companies in Brassov and Sibiu. Hagi Constantin Pop was a leading representative of the great merchants, and his company, with its headquarters in Sibiu, dominated Wallachian commerce between 1768 and 1836. It should be mentioned that, at that time, the term "Greek" was less a designation of ethnicity than a reference to the Orthodox religion (Hitchins 1996, p. 106). In fact, many of the merchants were Aromanians or even Romanians from Wallachia (Soroştineanu 2014, p. 39). A few of them might have had Transylvanian origins. The members of the companies took care not only to obtain commercial privileges, but also to affirm their religious status, establishing Orthodox parishes in the cities in which they settled (Boicu 2017, p. 51). The first Orthodox chapels and churches in Sibiu were founded by the families of these merchants.

As evidenced by the inscription placed in the altar, next to the table of oblation, Biserica din Groapă was built "in 1788, in the days of the Most High Emperor Joseph the Second, at the expense of titled lady Stana Hagi Petru Luca. It was committed in 1789, but was broken all down. [In] 1802. it was rebuilt entirely from the foundation, at the expense of Hagi Constadin Pop, as the registry of this holy place shows".

The church, the parish house, and the elementary school, together with the money fund, were included in the foundation established by Hagi Constantin Pop, as evidenced by the documents kept in the archive. The contents of the archive highlight that each stage during the constitution of the movable and immovable heritage of the foundation, starting from the time of the first founders, was recorded in a precise manner, in endowment documents drawn up and authenticated by notaries. The registry mentioned in the inscription included nothing more than the sum of the property certificates registered in the land book of the city.

In a document from 1870, which will be referred to below, the patronage status of the church is reaffirmed, along with the fact that "the internal fund of the church used to be the private property of Hagi Constandin Popp's family and that family, at its own expense, raised the church from its own funds", endowing it with all the necessary objects of worship. ${ }^{10}$

\subsection{The Content of the Document and Its Importance}

The property document of 1814 is, as we have shown, the oldest of the documents kept in the archive of the church. By issuing it, the cession of the right of property on certain lands in the Iosefin district, owned by the widow of the merchant Hagi Constantin Pop, in favor of the Annunciation Church, was sealed. In addition, a unification of the respective areas was achieved, with the resulting parcel to be marked as such in the cadastral register of the city.

The land mentioned in the act is undoubtedly the one upon which the church, the parish house, the old school, and the cemetery of the parish were built and upon which they stand to this day. The extract of the land book from 2007 mentions the area of $3871 \mathrm{~m}^{2}$ of the entire land belonging to the church. If the dimensions mentioned in the document are converted into a metric system $(1$ fathom $=1896 \mathrm{~m})$, the land in question had a length of $69.52 \mathrm{~m}$ and a width of $55.93 \mathrm{~m}$, resulting in an area of 3888.25 square meters. Bearing in mind the measurement technique used and the relatively small dimensions of the land, the measured and the calculated values may differ from the physical dimensions. Further modifications of the surface of the land owned by the church should not be excluded.

The deed of ownership was signed and stamped by (Johann Michael) Karl von Sonnenstein (1781-1836) on behalf of the land book authority. He was a member of the Gubernialrat, the Legislative Assembly of the Principality of Transylvania (Pleimes 2018). He belonged to a family of Saxon noble senators from Sebes, his father being a notary and his grandfather a royal judge (Buschak and Irrgang 1879, p. 588). Martin Binder, the one who issued and paraphrased the act on

10 BG, Ioan Panovici, Ioan Oniţiu and Antoniu Bechniţiu to Andrei Șaguna, 3 February 1870, Arhiva parohială, doc. 31/870. 
behalf of the magistrate of the Sibiu chair, was born in Mediaș. When he married in 1812, he was "Magistrats-Cancellist", a civil servant in the magistrate's chancellery. ${ }^{11}$

Beyond its legal significance, the document drafted in 1814 is able to clarify the circumstances under which the patrimony of the foundation sponsored by the members of that wealthy family of the city was established. The endowment of the church in the Iosefin district was a good execution of a testamentary request of the principal founder. Hagi Constantin Pop died on October 18/30, 1808, and at that moment, the time was approaching, according to the church ordinances, for the proper seven-year requiem service. It was, therefore, an opportune moment for his last wishes to be fulfilled by those who had inherited his significant wealth, including the responsibility to continue the philanthropic projects through which he distinguished himself throughout his life. His wife, of course, was most interested in taking on this role. Daughter of merchant Hagi Petru Luca and of Stana Petru Luca, Păuna- "who was affectionately called Păunica or Păuniţa, while the Saxons and other foreigners in the city knew her as Paulina" (Iorga 1906b, p. IV)—was recognized in 1802 as a co-founder of the Annunciation Church. She is mentioned, along with her husband and her mother, in the votive inscription on the circumference of the triumphal arch of the nave.

Zenovie Hagi Constantin Pop was, since 1809, after the death of both his father and his brother, Constantin (Dincă), the manager of the prestigious Sibiu trading house. At the insistence of Păuna, he gave up, with great difficulty, his military career, about which he was passionate, to become a businessman instead. However, he had neither the interest nor the acumen for such an occupation and probably never would have succeeded in taking over the complicated network of relations his father had woven without the support and guidance of long-time associate of the firm and trusted family man, merchant Stan Ştefan Popovici.

All three of them, in 1814, were concerned about ensuring the durability of the philanthropic project initiated by Hagi Constantin Pop through good fund administration and new donations. In this context, one can rightly understand the gesture of Păuna, who renounced, in favor of the foundation, the ownership of the lands she held in the Iosefin neighborhood, on whose perimeter her husband had formerly built the church and school, as well as the action of Stan Popovici, who had built a parochial house, which he then left, by will, as an inheritance to the same church. ${ }^{12}$ Starting in 1814 and then during the following year, Zenovie Pop took care to completely restore the icons on the iconostasis of the church founded by his parents (Iorga 1906a, pp. 239-40).

\subsection{Events that Followed the Document of 1814}

The administration of the foundation passed, during the life of the last descendant in the male line of the family of founders, Zenovie H. Constantin Pop, to the hierarchs of the Orthodox Church in Transylvania, starting with bishop Andrei Şaguna. The bishop himself informed the parish priest Ioan Panovici about that transfer of administrative authority in a letter dated 23 February $1850,{ }^{13}$ but the official transfer of authority took place on May 10, 1854, in the form of a donation certificate, signed by the patron of the foundation, Zenovie H. Constantin Pop. The High Lieutenancy of Transylvania-the provincial government established in 1852 by imperial decree (Brusanowski 2010, pp. 91-92)—approved the act in the same year, 1854 .

Both the patronage character of the foundation, as well as its right of administration, passed exclusively to the Orthodox bishop of Transylvania and had to be reconfirmed after the enactment in 1868 of the Organic Statute of the Greek-Eastern Romanian Church in Hungary and Transylvania. This law established that ecclesiastical assets should be administered by the parishes. Articles 1 to 3 of the Statute provided that a new parish could not be established if there was not a community with a

11 ELS, Auszüge der Traumatrikel Hermannstadt Band VI-a (1786-1812). p. 189.

12 BG, Donation act of Stan Ștefan Popovici, 1850, Arhiva parohială, doc. IV/1850N.

13 BG, Andrei Șaguna to Ioan Panovici, 23 February 1850, Arhiva parohială, doc. 134/850. 
sufficient number of believers who could support it materially (Biserica Greco-Orientală Română din Ungaria și Transilvania BGOR, pp. 9-10). It was therefore necessary to emphasize that, due to the special status of the church in the Iosefin district of Sibiu, it was exempted from such a provision. The priest Ioan Panovici and two representatives of the parish, the lawyer Ioan Oniţiu and the merchant Antoniu Bechniţiu, addressed this issue a memorandum to Metropolitan Şaguna on February 3, 1870, asking him to arrange how this case should proceed.

As it is also known to us-the authors of the memorandum showed at the end - the patron of the above-named church-the latter-Mr. Baron Zinovie H. Constandin Popp, together with all his legacy heir family, handed over the patronage of this church to Your Excellency and the followers of Your Excellency as openly shows the Widmungs-Urkunde ${ }^{14}$ of the acclaimed patronage. On 10 May 1854 he gave it to Your Excellency and on October 19 of the same year, you endured to receive it. On 31 October 1854 it has been confirmed under No. 20259/2559 by the Transylvanian Lieutenancy. Therefore, in this church there is nobody except Your Excellency to dispose. ${ }^{15}$

Their opinion was also shared by the metropolitan, according to the resolution made by him in several lines noted under the signature at the end of the last page of the document.

The passing of the right to administer the foundation to the Orthodox archbishop-at the wish of Păuna, the widow of the founder Hagi Constantin Pop, but fulfilled only after her death by Zenovie Pop-represented a legal act, established by an imperial decree of Francis I of Austria (1792-1835) and was acquired as such by the successors of the metropolitan Andrei Şaguna (Soroştineanu 2006, p. 33). In practice, the foundation was administered by the Archdiocese Consistory, whose president was the metropolitan as provided by the Organic Statute, articles 132-137 and 159-161 (Biserica Greco-Orientală Română din Ungaria și Transilvania BGOR, pp. 45-47, 54).

The founding act from 1854 was not included as an additional article in the Organic Statute, so there were subsequent debates about the statute of the Annunciation Church. The authors of the abovementioned 1870 memorandum claimed that, when the church was built, "the people in the suburb of Josephstadt did not even pay a sand cart for the church". In a meeting in 1884 of the Synod of the Greek-Eastern Archdiocese, deputy Dimitrie Comșa raised the question of whether the Annunciation Church was patronized or not because the parish house needed urgent repairs (Soroştineanu 2014, p. 51). Eleven years later, the same deputy claimed that the situation of the church in the Iosefin suburb was still "pseudo-constitutional", i.e., that it was not in harmony with the Organic Statute (Arhidieceza Greco-Orientală din Transilvania AGOT, pp. 48-49). In 1899, the matter was again discussed. The Archdiocese Consistory argued that the archbishop's patronage right was exercised on the basis of the decree of Emperor Francis I of Austria of 1823, following the request of Paulina Hagi Pop, and on the founding act of May 10, 1854. Even after that, Dimitrie Comşa reiterated the request that the situation of the church in Iosefin be regulated by the Organic Statute (Arhidieceza Greco-Orientală din Transilvania AGOT, pp. 63-64). At a later meeting (1900), the proposal to regulate the situation through the Organic Statute was eventually rejected, and it was decided that the church in the Iosefin district would continue to be patronized, according to the provisions of the founding document (Arhidieceza Greco-Orientală din Transilvania AGOT, pp. 84-85).

The foundation of Hagi Constantin Pop enjoyed this special arrangement, based on the old Romanian legal norms regarding foundations, until the establishment of the Communist regime. After the enactment of a new law on the organization and functioning of religious cults in $1949,{ }^{16}$ the right of ownership of the foundation of the church, the land, and the buildings related to it, as well as the

14 Certificate of donation (German).

15 BG, Ioan Panovici, Ioan Onițiu and Antoniu Bechniţiu to Andrei Șaguna, 3 February 1870, Arhiva parohială, doc. $31 / 870$.

16 (Biserica Ortodoxă Română BOR, articles 175-177). 
testamentary conditions established by the founders and other donors who contributed over time to the increase of the Hagician Fund, were cancelled.

\section{Conclusions}

The document presented above is preserved in the archive of Biserica din Groapă in Sibiu and has not been published until now. Through this act, the lands owned by the widow of merchant Hagi Constantin Pop in the Iosefin neighborhood were donated to the Annunciation Church. In addition, a unification of the respective areas was achieved, with the resulting parcel of land recorded as such in the cadastral register of the city. The document issued by the municipal administration also represented the ownership of the church with respect to the land.

The content of the act is relevant to the circumstances under which the patrimony of the foundation sponsored by the members of Hagi Constantin Pop's family was established. Starting in 1850, the foundation passed to the administrative authority of the Orthodox hierarchs of Transylvania. The foundational documents also conferred a special status, with the Annunciation Church being exempted from the provisions of Andrei Şaguna's Organic Statute until 1949.

Regarding the status of the Romanian Orthodox Church, the document does not say more than what is known to us from other sources of the time. The Orthodox Church had full freedom to profess its religion but, although tolerated, had to sustain itself without financial support from the state (Mildenberg 1837, pp. 50-51, 212-16). Nevertheless, the document attests that the property of the Orthodox Church was recognized and guaranteed by law. Some members of that church, such as Paulina Hagi Pop, were highly valued persons in Sibiu. This explains the reverential epithet of "much praised" with which the local magistrate addressed her and the church founded by her. There were other people of Romanian origin who owned land in the Iosefin suburb but who did not enjoy the same consideration, as evidenced by the way to which they were referred in the document (e.g., "unmarried female person called Țața Floarie").

In addition to the direct effects of the document, to which we referred above, the existence of indirect consequences is indisputable. The Annunciation Church not only nourished the spiritual needs of the Orthodox Romanians, but also contributed to the strengthening of their national identity. The church and its founders were the crucible for the material and cultural progress of the Romanians living in the Iosefin suburb, and we may assume that their contribution to the economic and social life of Sibiu increased in the first decades of the eighteenth century. The school of the church presumably contributed to a better education for the Romanians.

We used archival research in this article to present the historical context and the consequences of the donation act issued in 1814. These consequences mainly referred to the issue of the church's patrimony, as the nature of the investigated document is patrimonial. However, further investigation of the archive could provide important data about the Romanian school and education in religious schools in the nineteenth century and about the relations of the Iosefin community with the villages around Sibiu and with the Romanian Principalities (Wallachia and Moldavia), as well as with the authorities in Sibiu and Vienna.

Author Contributions: Conceptualization, C.O. and I.O.A.; methodology, C.O. and I.O.A.; transcription, translation, and notes on the German document, C.O.; discussion, I.O.A.; data curation, I.O.A.; writing-original draft preparation, C.O. and I.O.A.; writing-review and editing, C.O.; funding acquisition, C.O. All authors have read and agreed to the published version of the manuscript.

Funding: This research was funded by Lucian Blaga University of Sibiu \& Hasso Plattner Foundation research grants LBUS-IRG-2019-05.

Acknowledgments: The authors would like to express their gratitude to Petru Madina, parish priest of the Annunciation Church, for allowing them to reproduce here images of the document; Wolfgang G. Pleimes, for the kindness with which he provided the bibliographical sources referring to Karl von Sonnenstein and Franz Binder.

Conflicts of Interest: The authors declare no conflict of interest. The funders had no role in the design of the study; in the collection, analyses, or interpretation of data; in the writing of the manuscript; or in the decision to publish the results. 


\section{References}

\section{Archival Documents from Sibiu, Romania}

BG (Abbreviation for Biserica din Groapă).

ELS (Abbreviation for Evangelische Landeskirche in Siebenbürgen).

BG, Donation Act of Paulina Pop, 22 May 1814, Parish Archive, doc. 660/1814.

BG, Handover report, 27 October 1879, Parish Archive, doc. 3022/879.

BG, Ioan Panovici, Ioan Oniţiu and Antoniu Bechniţiu to Andrei Șaguna, 3 February 1870, Parish Archive, doc. $31 / 870$.

BG, Donation act of Stan Ștefan Popovici, 1850, Parish Archive, doc. IV/1850N.

BG, Andrei Șaguna to Ioan Panovici, 23 February 1850, Parish Archive, doc. 134/850.

ELS, Auszüge der Traumatrikel Hermannstadt Band VI-a (1786-1812). Zentralarchiv der evangelischen Landeskirche in Siebenbürgen.

\section{Secondary Sources}

Abrudan, Ioan Ovidiu. 2013. Contribuţie la cunoaşterea unei valoroase piese de artă liturgică-iconostasul Bisericii din Groapă. Revista Teologică 2: 121-39.

Arhidieceza Greco-Orientală din Transilvania (AGOT). 1897. Protocolul Sinodului Arhidiecezei greco-orientale române din Transilvania tinut la anul 1897. Sibiu: Tipariul tipografiei archidiecesane.

Arhidieceza Greco-Orientală din Transilvania (AGOT). 1899. Protocolul Sinodului Arhidiecezei greco-orientale române din Transilvania tinut la anul 1899. Sibiu: Tipariul tipografiei archidiecesane.

Arhidieceza Greco-Orientală din Transilvania (AGOT). 1900. Protocolul Sinodului Arhidiecezei greco-orientale române din Transilvania tinut la anul 1900. Sibiu: Tipariul tipografiei archidiecesane.

Beethoven, Ludwig van. 1816. "Wellingtons Sieg oder die Schlacht bei Vittoria" für Orchester op. 91, nr. 2363, Wien: Steiner. Beethoven-Haus C 91/13, Bonn. Available online: https://da.beethoven.de/sixcms/detail.php? \&template=dokseite_digitales_archiv_en\&_dokid=bb:t00047857\&_seite $=1--4$ (accessed on 17 January 2020).

Biserica Greco-Orientală Română din Ungaria și Transilvania (BGOR). 1900. Statutul Organic al Bisericei Greco-Orientale Române din Ungaria și Transilvania, cu un Suplement. Sibiu: Tiparul Tipografiei Arhidiecesane.

Bodogae, Teodor. 1981. Sibiul, vatră de vieţuire ortodoxă românească. In Arhiepiscopia Sibiului-vatră de istorie. Edited by Mitropolia Ardealului. Sibiu: Editura Centrului Mitropolitan, pp. 13-22.

Boicu, Dragoș. 2017. «Ca o cenuşotcă modestă, în dosul edificiilor, cari o încunjuoară»-pe urmele Bisericii companiştilor greci din Sibiu. Transilvania 1: 50-59.

Biserica Ortodoxă Română (BOR). 1949. Statutul pentru organizarea și funcționarea Bisericii Ortodoxe Române. Biserica Ortodoxă Română 1-2: 87-136.

Brusanowski, Paul. 2007. Pagini din istoria bisericească a Sibiului medieval. Cluj-Napoca: Presa Universitară Clujeană.

Brusanowski, Paul. 2010. Învăţământul confesional ortodox român din Transilvania între anii 1848-1918: Între exigenţele statului centralist şi principiile autonomiei bisericeşti. Cluj-Napoca: Presa Universitară Clujeană.

Buschak, and Irrgang. 1879. Genealogisches Taschenbuch der Ritter-und Adels-Geschlechter, Vierter Jahrgang. Brünn: Druck und Verlag von Buschak \& Irrgang.

Czeike, Felix. 2004. Historisches Lexikon Wien. Vol. 3. H-L. Wien: K\&S.

Deuser, Hermann, and Richard Purkarthofer, eds. 2005. Deutsche Søren Kierkegaard. Band 1: Journale und Aufzeichnungen. Journale AA, BB, CC, DD. Berlin: De Gruyter.

Freyhan, Michael. 2009. The authenthic Magic Flute libretto: Mozart's autograph or the first full-score edition? Plymouth: Scarecrow Press.

Gernrath, Johann Conrad. 1825. Abhandlung der Bauwissenschaften oder Theoretisch-praktischer Unterricht in der gemeinen bürgerlichen Baukunst, in dem Strassenbau (etc.). Brünn: J. G. Gastl.

Goerg, Joseph Schmidt. 1978. Die Wasserzeichen in Beethovens Notenpapieren. In Beiträge zur BeethovenBibliographie, Studien und Materialien zum Werkverzeichnis von Kinsky-Halm. Edited by Kurt Dorfmüller. München: G. Henle, pp. 167-195.

Härtl, Heinz, ed. 2018. Ludwig Achim von Arnim Briefwechsel IV (1807-1808). Berlin: De Gruyter.

Hitchins, Keith. 1996. The Romanians, 1774-1866. Oxford: Clarendon Press.

Iorga, Nicolae. 1906a. Negoţul şi meşteşugurile în trecutul românesc. București: Minerva. 
Iorga, Nicolae. 1906b. Scrisori de boieri şi negustori olteni către Casa de Negoţ sibiană Hagi Pop publicate cu note genealogice asupra mai multor familii. Bucuresti: Atelierele grafice SOCEC \& Comp.

Iorga, Nicolae. 1906c. Scrisori şi inscripţii ardelene şi maramureşene. II. Inscripţii şi însemnări (formând volumul XIII din «Studii şi documente cu privire la Istoria Românilor»). București: Atelierele grafice SOCEC \& Comp.

Jäckel, Joseph. 1824. Zimmentirungs Lexikon für alle Handels-und Gewerbsleute nach den österreichischen Zimmentirungsschriften. Wien: Anton Strauß.

Jensen, Hans. 1969. Die Schrift in Vergangenheit und Gegenwart. Berlin: Deutscher Verlag der Wissenschaften.

Krüger, Johann Friedrich. 1830. Vollständiges Handbuch der Münzen, Maße und Gewichte aller Länder der Erde. Quedlinburg and Leipzig: Verlag Gottfried Basse.

Ludwig, Franz. 1828. Neuestes Conversations-Lexicon, oder Allgemeine Deutsche Real-Encyclopädie für gebildete Stände. Wien: Franz Ludwig, vol. 8.

Mildenberg, J. H. Benigni v. 1837. Handbuch der Statistik und Geographie des Großfürstenthums Siebenbürgen. 2. Heft. Hermannstadt: N. H. Thierry's Buchhandlung.

Păcurariu, Mircea. 2002. Cărturari sibieni de altădată. Cluj-Napoca: Dacia.

Păcurariu, Mircea. 2006. Scurta istorie a vieţii bisericeşti a Sibiului până la începutul secolului al XX-lea. Revista Teologică 2: 36-46.

Pleimes, Wilhelm aus Roesrath. 2018. Johann Michael Karl Conrad von Sonnenstein. Genealogische Datenbasis. Available online: https://gedbas.genealogy.net/person/show/1216406736 (accessed on 17 January 2020).

Reichsministerium für Wissenschaft, Erziehung und Volksbildung und der Unterrichts-Verwaltung der Länder. 1941. Schreibunterricht. RdErl. d. RMfWEV. v. 1. September 1941-E II a 334/41 E III, Z II a. Deutsche Wissenschaft Erziehung und Volksbildung. Amtsblatt des Reichsministeriums für Wissenschaft, Erziehung und Volksbildung und der Unterrichts-Verwaltung der Länder 17: 332-33. Available online: https://goobiweb.bbf.dipf. de/viewer/object/991084217_0007/347/ (accessed on 17 January 2020).

Roth, Harald. 2006. Hermannstadt. Kleine Geschichte einer Stadt in Siebenbürgen. Köln, Weimar and Wien: Böhlau.

Seidl, Johannes. 2006. Schriftbeispiele des 17. Bis 20. Jahrhunderts zur Erlernung der Kurrentschrift. Ubungstexte aus Perchtoldsdorfer Archivalien. Percholdsdorf: Marktgemeinde Percholdsdorf.

Sigerius, Emil. 1928. Vom alten Hermannstadt. 3 Folge. Hermannstadt: Verlag Krafft \& Drotleff.

Soroştineanu, Valeria. 2006. Despre catedrala mitropolitană din Sibiu. Transilvania 4: 33-36.

Soroştineanu, Valeria. 2010. Cimitirul Bisericii din Groapă din Sibiu. Studia Universitatis Cibiniensis. Series Historica 7: $135-52$.

Soroştineanu, Valeria. 2014. Biserica din Groapă și grecii din Sibiu. In Interferenţe culturale în Sibiul secolelor XVIII-XX. Edited by Ioan Popa and Mihaela Grancea. Sibiu: Astra Museum, pp. 37-57.

Steiner-Welz, Sonja. 2003. Von der Schrift und den Schriftarten. Mannheim: Reinhard Welz Vermittler Verlag Mannheim.

Teutsch, Friedrich. 1907. Geschichte der Siebenbürger Sachsen für das sächsische Volk. 2. Band. Hermannstadt: Druck und Verlag von W. Krafft.

Ventresca, Marc J., and John W. Mohr. 2017. Archival Research Methods. In The Blackwell Companion to Organizations. Edited by Joel A. C. Baum. Available online: https://doi.org/10.1002/9781405164061.ch35 (accessed on 10 February 2020).

Voorn, Henk. 1960. De papiermolens in de provincie Noord-Holland. Haarlem: Papierwereld.

Wien, Ulrich Andreas. 2017. Siebenbürgen-Pionierregion der Religionsfreiheit: Luther, Honterus und die Wirkungen der Reformation. Hermannstadt and Bonn: Schiller Verlag.

Ziesche, Eva, and Dierk Schnitger. 1995. Der handschriftliche Nachlass Georg Wilhelm Friedrich Hegels und die Hegel-Bestände der Staatsbibliothek zu Berlin Preussischer Kulturbesitz. Teil 2: Die Papiere und Wasserzeichen der Hegel-Manuskripte. Wiesbaden: Harrassowitz Verlag.

(C) 2020 by the authors. Licensee MDPI, Basel, Switzerland. This article is an open access article distributed under the terms and conditions of the Creative Commons Attribution (CC BY) license (http://creativecommons.org/licenses/by/4.0/). 